\title{
EFFECT OF TEMPERING TEMPERATURE ON PRECIPITATE EVOLUTION AND MECHANICAL PROPERTIES OF 34CrNiMo6 STEEL
}

\author{
VPLIV TEMPERATURE POPUŠČANJA NA POTEK IZLOČANJA IN \\ MEHANSKE LASTNOSTI JEKLA 34CrNiMo6
}

\author{
Yanming Ge, Kehong Wang* \\ School of Materials Science and Engineering, Nanjing University of Science and Technology, No. 200 Xiaolingwei Street, Nanjing, \\ Jiangsu 210094, China \\ Prejem rokopisa - received: 2018-11-20; sprejem za objavo - accepted for publication: 2019-01-30
}

doi: $10.17222 /$ mit. 2018.248

\begin{abstract}
The effect of the tempering temperature on mechanical properties are studied by investigating the precipitate evolution during the heat treatment of the $34 \mathrm{CrNiMo6}$ steel. Five different tempering temperatures are used at the same holding time of $3 \mathrm{~h}$. Then the mechanical properties of the 34CrNiMo6 steel are studied under steady-state conditions and impact conditions. The strength decreases while the elongation after breakage increases with the increasing tempering temperature. The impact-absorbing energy at $20{ }^{\circ} \mathrm{C}$ and $-40{ }^{\circ} \mathrm{C}$ increases with the increasing tempering temperature. Based on the experimental results, the recommended tempering temperature is $660{ }^{\circ} \mathrm{C}$. The differences in mechanical properties related to different tempering temperatures may be caused by the nucleation rate and growth of precipitates under different conditions. The spherification degree of cementite is more complete with the recommended tempering temperature, resulting in a decrease in mechanical properties and improvement of ductility.
\end{abstract}

Keywords: 34CrNiMo6 steel, tempering temperature, mechanical properties, precipitates

Avtorji so raziskovali vpliv temperature popuščanja na mehanske lastnosti jekla 34CrNiMo6 s preučevanjem poteka izločanja med njegovo toplotno obdelavo. Izvedli so preizkuse popuščanja pri petih (5) različnih temperaturah in v vseh primerih enakem (3-urnem) času zadrževanja preizkušancev na teh temperaturah. Nato so določili mehanske lastnosti toplotno obdelanega jekla pri stacionarnih in udarnih (dinamičnih) pogojih preizkušanja. Trdnost preizkušancev se je zmanjševala in raztezek je naraščal z naraščajočo temperaturo popuščanja. Udarna žilavost pri $20^{\circ} \mathrm{C}$ in $-40{ }^{\circ} \mathrm{C}$ je naraščala z naraščajočo temperaturo popuščanja. Na osnovi eksperimentalnih rezultatov avtorji priporočajo temperaturo popuščanja $660^{\circ} \mathrm{C}$. Ugotavljajo, da so razlike v mehanskih lastnostih posledica različnih pogojev toplotne obdelave, ker sta hitrost nukleacije in potek rasti izločkov pri različnih temperaturah popuščanja različna. Stopnja sferifikacije (okroglenja) cementita se stopnjuje $\mathrm{z}$ naraščajočo temperaturo popuščanja, kar posledično vodi do zniževanja trdnosti in povečevanja duktilnosti jekla.

Ključne besede: jeklo 34CrNiMo6, temperatura popuščanja, mehanske lastnosti, izločki

\section{INTRODUCTION}

The modern development of the commercial windpower industry started in the 1970 s in the United States before spreading to Europe where Denmark and Germany became significant champions of the technology. ${ }^{1}$ Later, the focus of its growth was shifted to Asia and particularly to China where there was a massive development of wind power during the past decade. So, the wind energy is one of the fastest growing sources of electricity and it is nowadays capable of providing power in most parts of the world. ${ }^{2}$ According to the estimation of the International Energy Agency (IEA), the annual wind-generated electricity of the world will reach 1282 TW h by 2020 . By 2030, the annual wind-generated electricity will reach $2182 \mathrm{TW}$ h. ${ }^{3}$ That requires the wind turbines to exhibit a higher safety and reliability, with the power of wind turbines increasing from kilo-watt class to million-watt class. ${ }^{4}$ That is to say, the mechanical

*Corresponding author's e-mail:

wkh1602@126.com properties of the material used for making the main bearings should meet the related demands. 5 The $34 \mathrm{CrNiMo6}$ steel is one kind of heat-treated low-alloy steel with a high hardenability and strength, which contains nickel, chromium, and molybdenum. ${ }^{6}$ Moreover, the 34CrNiMo6 steel exhibits very good toughness properties with a Charpy V-notch at a very low temperature. Hence, the $34 \mathrm{CrNiMo6}$ steel is widely used for making the wind-turbine main shaft. ${ }^{7}$ In the actual production process, the typical heat treatment of this steel involves two stages, quenching and tempering. ${ }^{8}$ The 34CrNiMo6 steel can obtain high strength after quenching to a full martensitic microstructure, while the ductility and toughness can be improved with tempering.

N. Popescu et al. ${ }^{9}$ studied the effects of bulk tempering on the hardenability and temperability of the 34CrNiMo6 steel. The experiment investigated the correlation between the hardness achieved after high tempering of products and their equivalent diameter and the heat and time parameters of tempering. J. Cochet et al. ${ }^{10}$ investigated the heat-treatment parameters of the 
34CrNiMo6 steel used for shackles. The results firstly provided a validation of the input data and the prediction of the phase volume fractions and the resulting hardness, which showed that the proposed approach could yield a very good representation of the material properties. The results showed that the heat-treatment method could significantly improve the mechanical properties via changing the nucleation rate and growth rate of austenite. However, there are very few researches about the specific effect of the tempering temperature on the microstructure and mechanical properties of the $34 \mathrm{CrNiMo6}$ steel during a tempering process.

One of the most important things for a production company is to provide high-quality products, which should meet the certification standard because any failure during the actual service time is costly and dangerous. The fault statistics for a wind turbine in Figure 1 shows that the outages caused by the main-shaft failure account for less than $0.1 \%$ (marked in blue), but its downtime accounts for a very large share, about $24.8 \%$ (marked in orange). ${ }^{11}$ So it is necessary to investigate the mechanical properties of the $34 \mathrm{CrNiMo6}$ steel for the wind-turbine main shaft obtained after the heat treatment.

The objective of this paper is to investigate the microstructure evolution and mechanical properties of the $34 \mathrm{CrNiMo6}$ steel by adopting different tempering temperatures after quenching. That could help us understand and optimize the heat-treatment process parameters that affect the microstructures, as well as determining the final mechanical properties of the $34 \mathrm{CrNiMo} 6$ steel for the wind-turbine main shaft. Firstly, we used five different tempering temperatures during the heat treatment. Then the mechanical-property tests involving tensile strength, yield strength, elongation after breakage and impact-absorbing energy under different conditions were carried out. To get a better understanding of the influencing mechanism of the tempering temperature on the microstructures evolution of the $34 \mathrm{CrNiMo6}$ steel, the metallographic results obtained with the optical microscope (OM), scanning electron microscope (SEM) and transmission electron microscope (TEM) were presented.

\section{EXPERIMENTAL PART}

\subsection{Sample preparation}

The material used for the present study is the heattreated low-alloy 34CrNiMo6 steel. The chemical composition of the material is shown in Table 1.

The heat treatment of the $34 \mathrm{CrNiMo6}$ steel involves two stages, quenching and high-temperature tempering (QT). Again, the steel could obtain high strength by quenching and improve its toughness due to tempering. Tables 2 illustrates the mechanical properties required in accordance with the certification of the $34 \mathrm{CrNiMo6}$ steel for the wind-turbine main shaft, and BS EN 10083-3:2006.

According to the actual measurement, a fracture position occurred in the variable-diameter section of the inner diameter of the main shaft. A schematic diagram of

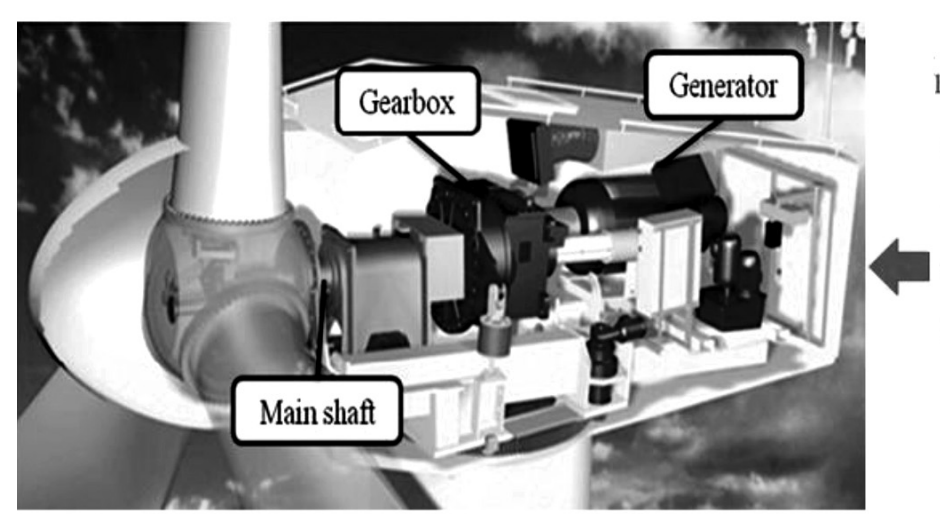

Fault statistics

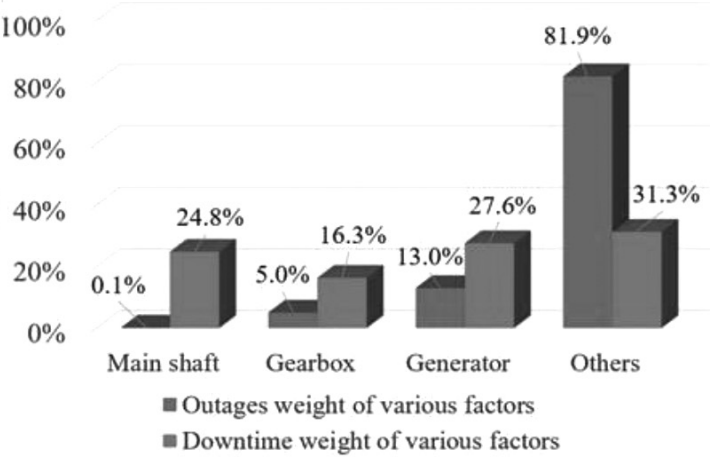

Figure 1: Outage and downtime weights of wind-turbine faults

Table 1: Chemical composition of 34CrNiMo6 steel

\begin{tabular}{|c|c|c|c|c|c|c|c|c|}
\hline Element & $\mathrm{C}$ & $\mathrm{Si}$ & $\mathrm{Mn}$ & $\mathrm{P}$ & $\mathrm{S}$ & $\mathrm{Cr}$ & $\mathrm{Mo}$ & $\mathrm{Ni}$ \\
\hline $\begin{array}{c}\text { Standard value } \\
\text { BS EN 10083-3:2006 }\end{array}$ & $0.30-0.38$ & 0.40 & $0.50-0.80$ & 0.025 & 0.035 & $1.30-1.70$ & $0.15-0.30$ & $1.30-1.70$ \\
\hline Measured value & 0.35 & 0.23 & 0.76 & 0.011 & 0.001 & 1.58 & 0.23 & 1.54 \\
\hline
\end{tabular}

Table 2: Mechanical properties of 34CrNiMo6 steel for the wind-turbine main shaft

\begin{tabular}{|c|c|c|c|c|}
\hline Test items & $\begin{array}{c}\text { Tensile strength } \\
R_{\mathrm{m}} / \mathrm{MPa}\end{array}$ & $\begin{array}{c}\text { Yield strength } \\
R_{\mathrm{e}} / \mathrm{MPa}\end{array}$ & Elongation $A / \%$ & $\begin{array}{c}\text { Impact absorbing energy } \\
\mathrm{AKV} / \mathrm{J}\end{array}$ \\
\hline $\begin{array}{c}\text { Standard value } \\
\text { BS EN 10083-3:2006 }\end{array}$ & $1100-1300$ & $\geq 900$ & $\geq 10$ & $\begin{array}{c}\geq 100\left(+20{ }^{\circ} \mathrm{C}\right) \\
\geq 90\left(-40^{\circ} \mathrm{C}\right)\end{array}$ \\
\hline
\end{tabular}




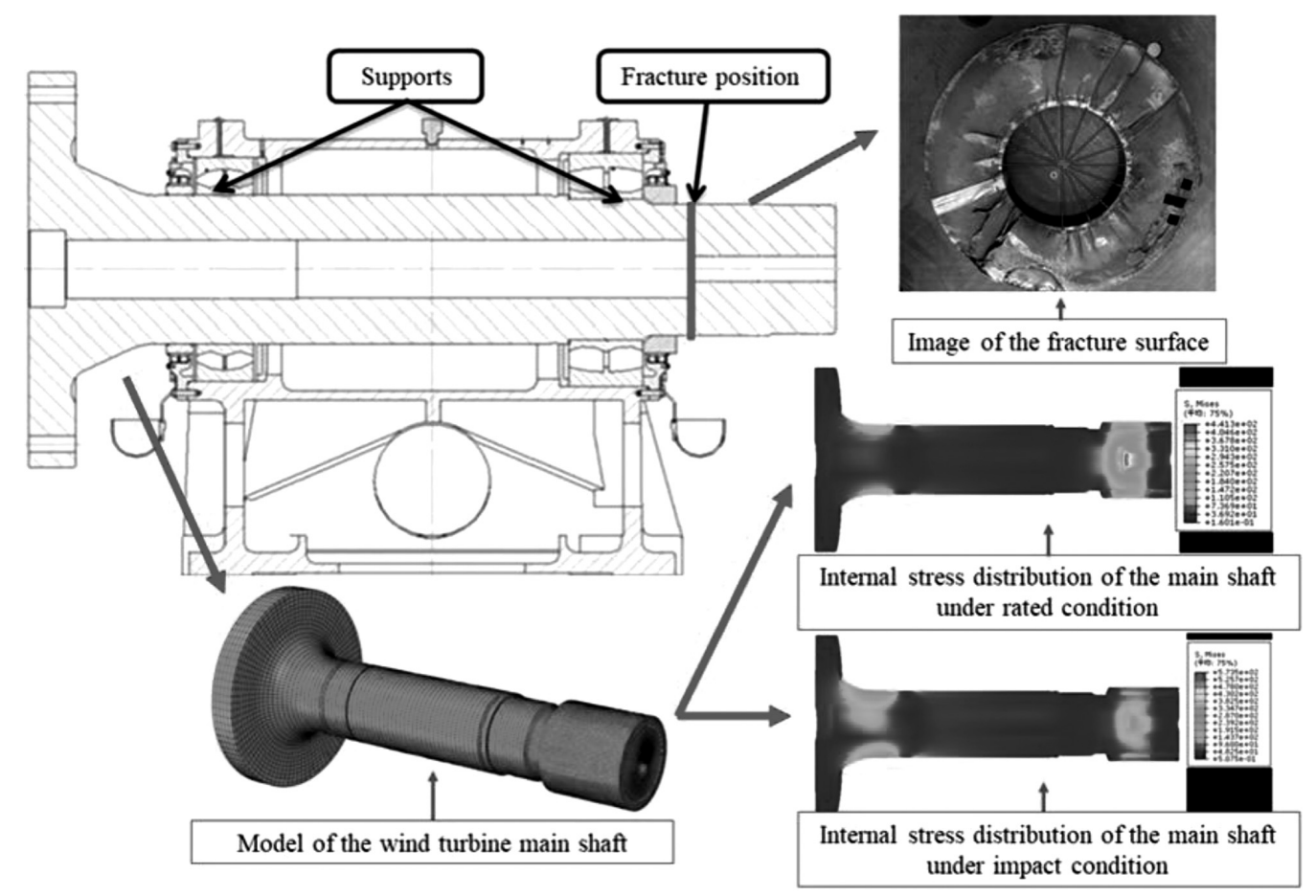

Figure 2: Outage and downtime weights of wind-turbine faults

the wind-turbine main shaft is shown in Figure 2. The image of the fracture surface is shown on the right. According to the finite-element-method simulation, we can tell that the positions of the maximum internal stress of the main shaft are always located at the center of the variable section under both steady-state conditions and impact conditions. ${ }^{12}$ So, the specimens used in this experiment were taken from the variable-diameter section.

\subsection{Tempering treatment and performance tests}

The heat treatments of the $34 \mathrm{CrNiMo6}$ steel consist of several steps, each of them having a specific purpose. Specifically, the tempering process is to reduce the brittleness, relieve the internal stress, and obtain relatively good microstructures. The tempering process includes heating the martensitic steel to the value below the low transformation temperature (A1), holding it at this temperature for a specified period and then cooling it down to room temperature, which makes the 34CrNiMo6 steel achieve the combination of desired mechanical properties. ${ }^{13}$ The most important process parameters during tempering are the tempering temperature, the holding time and the steel chemical composition. ${ }^{14}$ The tempering temperature can be identified according to the superficial color during the heating and the holding time can be determined by the product size. Generally, the larger the product size, the more time is needed for heating the material to the tempering temperature. On the other hand, the temperature and holding time are interdependent parameters in the tempering process. So, a range of mechanical properties can be obtained with the right combination of the tempering temperature and holding time, as shown in Figure 3.

In this experiment, we designed five different tempering temperatures to investigate the effect of the tempering temperature on the microstructure and mechanical properties of the 34CrNiMo6 steel. As shown in Table 3, five different tempering temperatures were adopted while the holding time remained the same.

Table 3: Heat-treatment conditions

\begin{tabular}{|c|c|c|c|}
\hline $\begin{array}{c}\text { Sample } \\
\text { no. }\end{array}$ & $\begin{array}{c}\text { Austenitizing } \\
\text { temperature } /{ }^{\circ} \mathrm{C}\end{array}$ & $\begin{array}{c}\text { Tempering } \\
\text { temperature } /{ }^{\circ} \mathrm{C}\end{array}$ & $\begin{array}{c}\text { Holding time } \\
/ \mathrm{h}\end{array}$ \\
\hline 1\# & 870 & 570 & 3 \\
\hline $2 \#$ & 870 & 600 & 3 \\
\hline $3 \#$ & 870 & 630 & 3 \\
\hline 4\# & 870 & 660 & 3 \\
\hline $5 \#$ & 870 & 690 & 3 \\
\hline
\end{tabular}

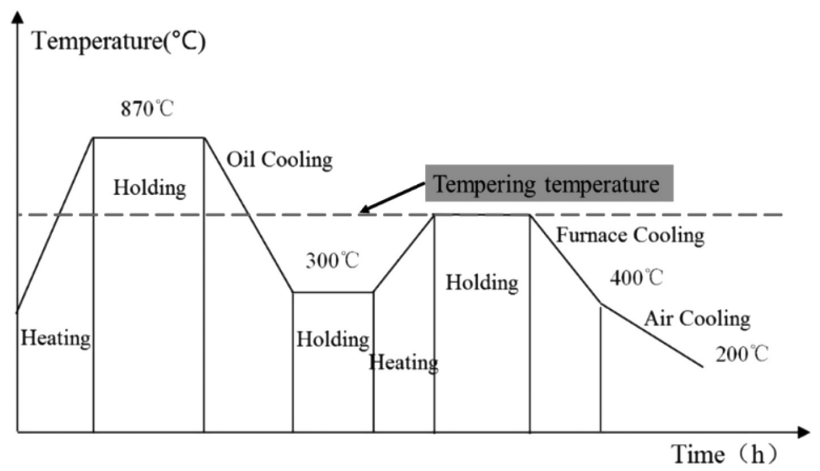

Figure 3: Flow chart of the main-shaft heat treatment 
This wind-turbine main shaft needs to exhibit high levels of strength and toughness over an extended period. Accordingly, the related tests were carried out to verify the mechanical properties according to standard specifications. The mechanics-performance testing contains tensile strength, yield strength, elongation after breakage and impact-absorbing energy test. Strength is one of the main mechanical properties of metals and alloys, defined as the amount of stress that a material can withstand while being stressed or compressed before failing. Toughness is known as the capability of the metal to resist the fracture by absorbing impact energy and becoming plastically deformed. Fracture toughness is used to characterize toughness. An impact test is used to obtain an indication of fracture toughness through measuring the resistance of a material to impact load without fracture, ${ }^{15}$ which is a tool for evaluating the ductile-brittle transition temperature. In addition, hardness is also a very important parameter of a material as it is a measure of the resistance to localized plastic deformation induced by either mechanical indentation or abrasion.

A tensile test is based on the ASTM E8 standard: a specimen is taken from the $1 / 4$ position of the circular cross-section of the $34 \mathrm{CrNoMo} 6$ steel, whose original diameter is $10 \mathrm{~mm}$, original standard distance is $50 \mathrm{~mm}$ and total length is $120 \mathrm{~mm}$. Our tensile test was carried
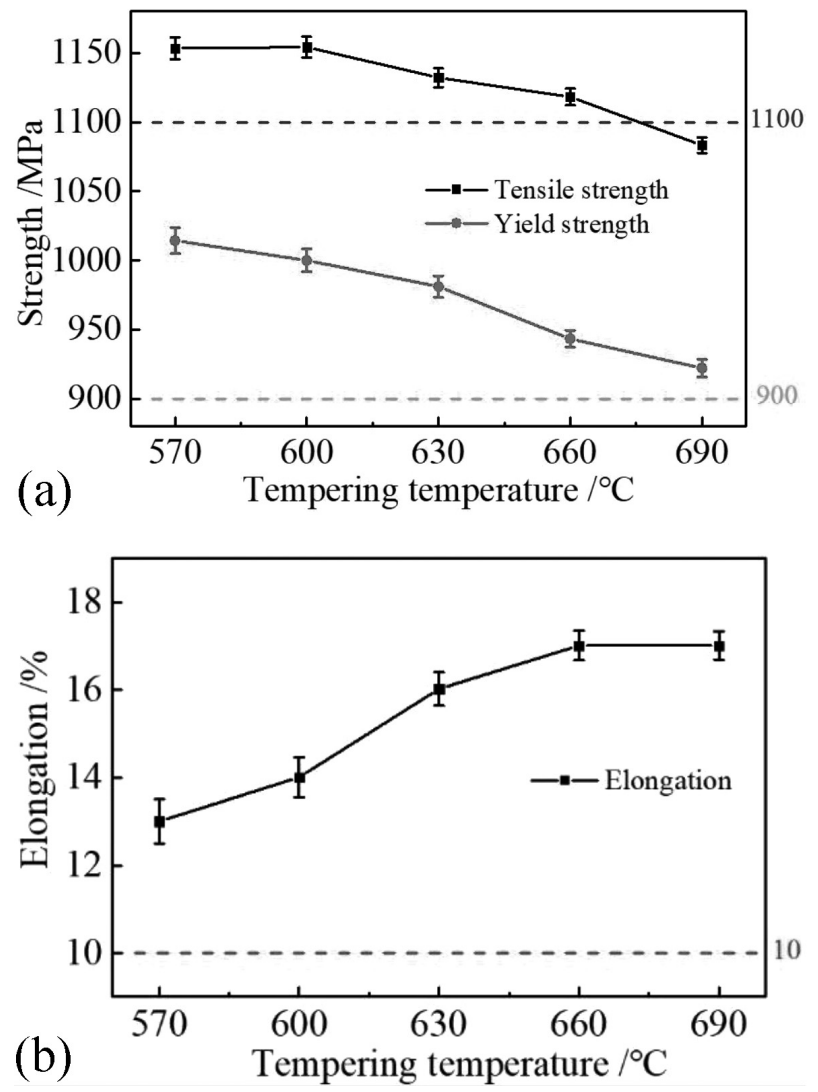

Figure 4: Evolutions of strength and elongation with the tempering temperature: a) tensile strength and yield strength, b) elongation after breakage out via a WAW-300B hydraulic universal tester. The samples were tested 3 times, and the test results were averaged for each group of the samples.

According to the ASTM A370-2013a standard, impact tests are carried out to measure impact-absorbing energy. The specimen is shaped as the V-type, taken from the $1 / 4$ position of the circular cross-section of the $34 \mathrm{CrNoMo6}$ steel, whose total length is $50 \mathrm{~mm}$. Both the height and width of the section are $10 \mathrm{~mm}$, the notch angle is $45 \pm 2^{\circ}$ and the height of the notch at the bottom is $8 \mathrm{~mm}$. The impact tests were carried out with a ZBC2302 impact-testing machine. The samples were tested 3 times, and for each group of samples the test results were averaged.

The hardness test is based on the ASTM E18-2015 standard. All the sample surfaces were ground and polished before the hardness tests. After placing the samples in the hardness-testing machine, a load of $150 \mathrm{~kg}$ was applied on the samples. After the load was removed, the Rockwell hardness C (HRC) could be calculated.

The metallographic specimens exposed to all the heat-treatment conditions were suitably sectioned, mounted, mechanically polished and etched; the etchant was 4 w/\% nital. The microstructural observations of these specimens treated with standard metallographic procedures and the analyses of the fracture surfaces removed from the fractured tensile bars were carried out using a ZEISS $\Sigma$ IGMA field-emission scanning electron microscope (SEM), operated at $2.5 \mathrm{kV}$.

A transmission electron microscope (TEM) was used for a detailed examination of the precipitate evolution. TEM samples were cut by a spark-cutting machine and prepared by utilizing the conventional jet-polishing technique in a mixture of $5 \%$ perchloric acid and $95 \%$ glacial acetic acid (by volume). The process was carried out at $0{ }^{\circ} \mathrm{C}$ and a voltage of $20-30 \mathrm{~V}$, until the discs were perforated.

\section{RESULTS AND DISCUSSION}

\subsection{Effects on the mechanical properties}

The evolutions of strength and elongation with different tempering temperatures are shown in Figure 4, respectively.

As shown in Figure 4a, both the tensile strength and yield strength decrease with the increasing tempering temperature. In contrast, the elongation after breakage increases with the tempering temperature increasing up to $660{ }^{\circ} \mathrm{C}$, while remaining almost stable from $660{ }^{\circ} \mathrm{C}$ to $690{ }^{\circ} \mathrm{C}$. In accordance with the certification standard from Table 2, we could conclude that the integrated mechanical properties of the 34CrNiMo6 steel meet the demands when the tempering temperature is below $660{ }^{\circ} \mathrm{C}$. The tensile strength is lower than the required value when the tempering temperature is $690{ }^{\circ} \mathrm{C}$. From the above, the tempering temperature is recommended to be no more than $660{ }^{\circ} \mathrm{C}$. 


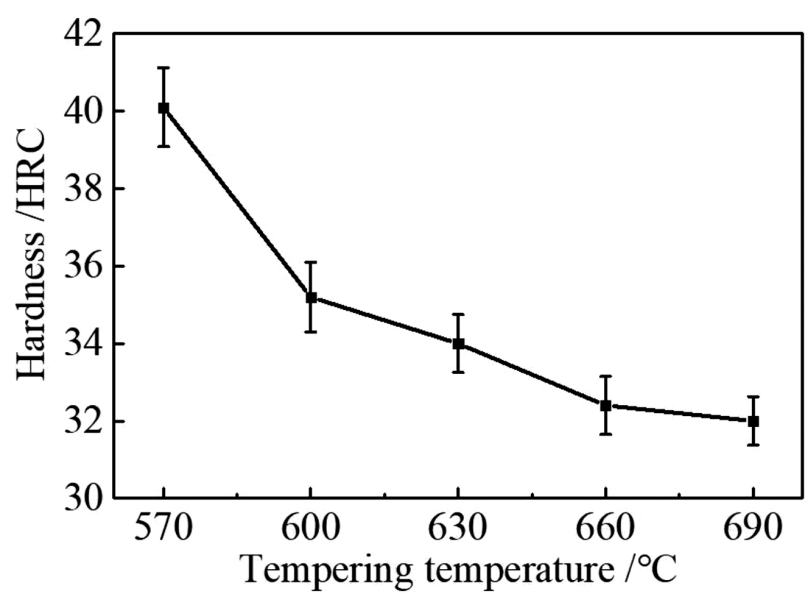

Figure 5: Evolutions of hardness with the tempering temperature

The evolution of the surface hardness with the tempering temperature is shown in Figure 5.

The Rockwell hardness $\mathrm{C}$ decreases with the increasing tempering temperature up to $660{ }^{\circ} \mathrm{C}$, while remaining almost stable from $660{ }^{\circ} \mathrm{C}$ to $690{ }^{\circ} \mathrm{C}$. According to the specification design, the surface hardness always meets the related requirements.

\subsection{Effect on the impact energy absorbed}

The evolutions of the impact-absorbing energy with the tempering temperature at different holding times are shown in Figure 6.

As shown in Figure 6, the impact-absorbing energy increases with the increasing tempering temperature, and reaches the peak value when the testing temperature is $20{ }^{\circ} \mathrm{C}$. Then the impact-absorbing energy decreases from $660{ }^{\circ} \mathrm{C}$ to $690{ }^{\circ} \mathrm{C}$. According to the specification design, the impact-absorbing energy meets the requirements when the tempering temperature is over $630{ }^{\circ} \mathrm{C}$. In contrast, the impact-absorbing energy increases monotonously with the increasing tempering temperature when the testing temperature is $-40{ }^{\circ} \mathrm{C}$, as shown in Figure 6 . According to the specification design, the impact-absorb-

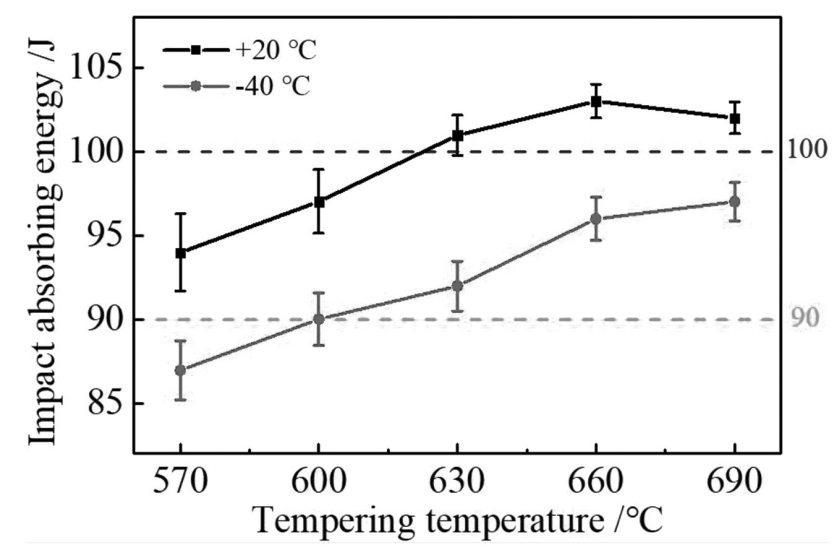

Figure 6: Evolutions of impact-absorbing energy with the tempering temperature under different temperatures ing energy meets the requirements when the tempering temperature is over $600{ }^{\circ} \mathrm{C}$.

According to the previous mechanical-performance test results and related certification standard, it is highly recommended that the tempering temperature should be between $630{ }^{\circ} \mathrm{C}$ and $660{ }^{\circ} \mathrm{C}$.

\subsection{Effects on the microstructures and fracture mor- phologies}

The metallographs of the 34CrNiMo6 steel after quenching and QT obtained with the OM are shown in Figure 7, respectively.

As previously mentioned, the 34CrNiMo6steel can obtain a high strength by being quenched to a full martensitic microstructure. According to the major morphologies, martensites can be divided into two main types, martensite lath and plate martensite. In this paper, the morphology of martensites consists mostly of dislocated martensite laths, as shown in Figure 7a.

After comparing the metallographs of the 34CrNiMo6 steel obtained with the OM under different tempering temperatures, the investigations of the samples point out that there are few differences among their microstructures. The microstructure recorded after tempering is shown in Figure $\mathbf{7 b}$. During the tempering process, the martensite decomposes and then transforms

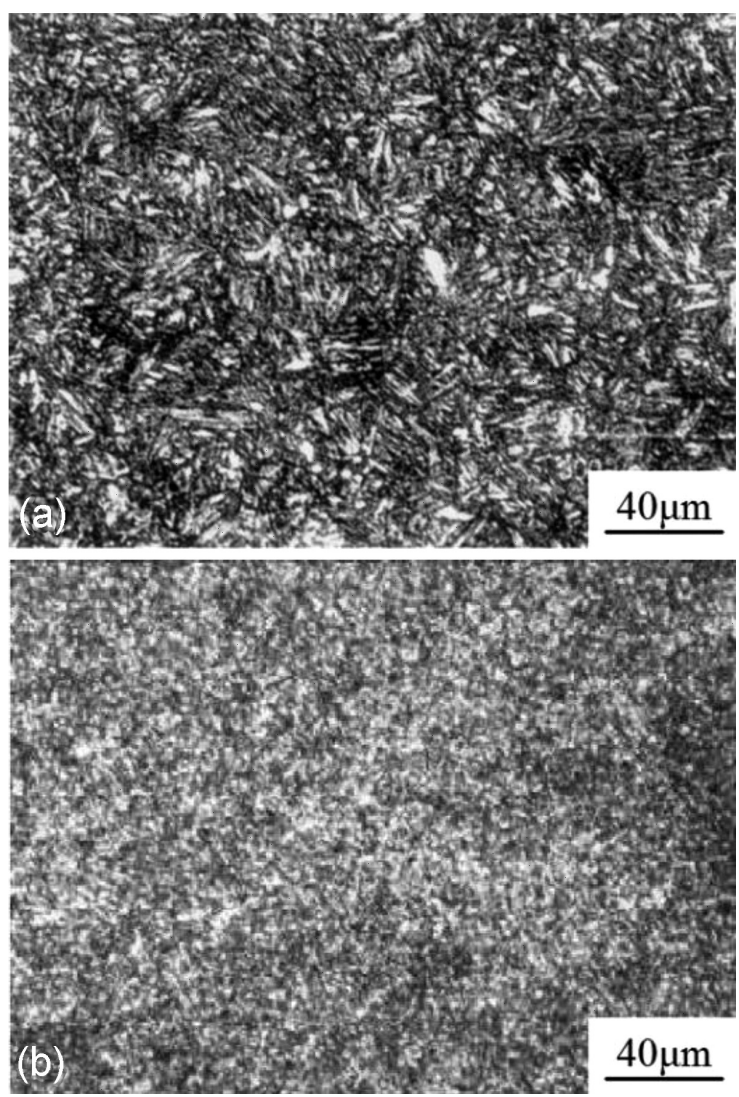

Figure 7: Metallographs of 34CrNiMo6 specimens quenched in oil $\left(870{ }^{\circ} \mathrm{C} / 30 \mathrm{~min}\right)$ and then tempered at $660{ }^{\circ} \mathrm{C}$ : a) quenched in oil $\left(870{ }^{\circ} \mathrm{C} / 30 \mathrm{~min}\right)$, b) quenched and tempered at $660^{\circ} \mathrm{C}$ 
into ferrite and the metastable phase of $\varepsilon$-carbide. Cementite is formed later and eventually the ferrite matrix recrystallizes. ${ }^{16}$ Most of the recrystallized ferrite has a chaotic ordering and interlocking structure that contributes to improving strength and toughness. So, the 34CrNiMo6 steel can obtain good integrated mechanical properties after the quenching and tempering processes.

To get a better understanding of the influencing mechanism of the tempering temperature on the microstructure of the $34 \mathrm{CrNiMo6}$ steel, micrographs of the 34CrNiMo6 steel after quenching and QT at different temperatures obtained with TEM are shown in Figure 8.
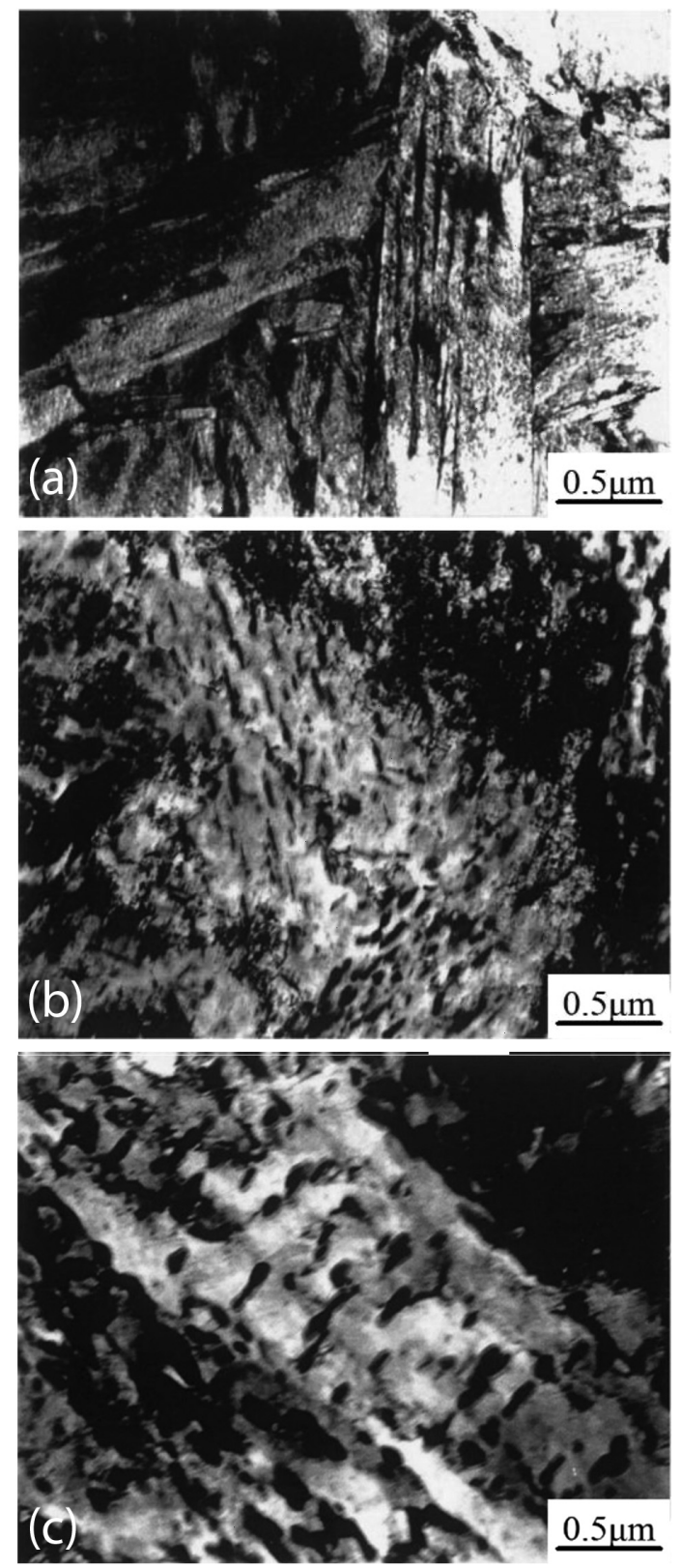

Figure 8: TEM micrographs of 34CrNiMo6 specimens quenched in oil $\left(870{ }^{\circ} \mathrm{C} / 30 \mathrm{~min}\right)$ and tempered at different tempering temperatures: a) as quenched in oil $\left(870{ }^{\circ} \mathrm{C} / 30 \mathrm{~min}\right)$, b) quenched and tempered at $570{ }^{\circ} \mathrm{C}$, c) quenched and tempered at $660^{\circ} \mathrm{C}$
Lath martensite is usually massive, having crystals shaped like interconnected plates and with nearly the same orientation, ${ }^{17}$ which can be found in Figure 8a. Moreover, the plate dimensions are limited by the dimensions of the austenite grains, which means that small martensite grains create a fine needle structure. ${ }^{18}$ This kind of structure has a relatively desirable microstructure. Micrographs of the $34 \mathrm{CrNiMo6}$ steel recorded at different tempering temperatures are shown in Figures $\mathbf{8 b}$ and $\mathbf{8 c}$. The microstructure always includes sorbite tempered at the tempering temperatures used in this experiment. Generally, tempered sorbite is a mixture of polygonal ferrite and relatively large cementite formations. ${ }^{18}$ Compared with the tempering temperature of $570{ }^{\circ} \mathrm{C}$, the spherification degree of cementite is more complete (Figure 8c) due to the higher temperature. ${ }^{19}$ As the grain boundary can inhibit the movement of dislocation, a reduction in the grain size can reduce the movement of dislocation, resulting in a significant effect on the mechanical properties. ${ }^{15}$ Hence, the tensile strength of the $34 \mathrm{CrNiMo6}$ steel decreases at $660{ }^{\circ} \mathrm{C}$ compared with that at $570{ }^{\circ} \mathrm{C}$. In contrast, the toughness of the $34 \mathrm{CrNiMo6}$ steel increases with the increasing tempering temperature due to the brittleness of cementite. The size of cementite has an effect on the mechanical behavior. Generally, a microstructure that consists of fine cementite is harder as well as stronger than that consisting of coarse cementite, whereas coarse cementite is more ductile.

TEM micrographs of the 34CrNiMo6 specimens quenched in oil $\left(870{ }^{\circ} \mathrm{C} / 30 \mathrm{~min}\right)$ and tempered at different tempering temperatures are shown in Figure 9.

As mentioned before, the microstructure is sorbite tempered under the heat-treatment conditions of this experiment, consisting of polygonal ferrite and cementite. The spherification degree of cementite is more
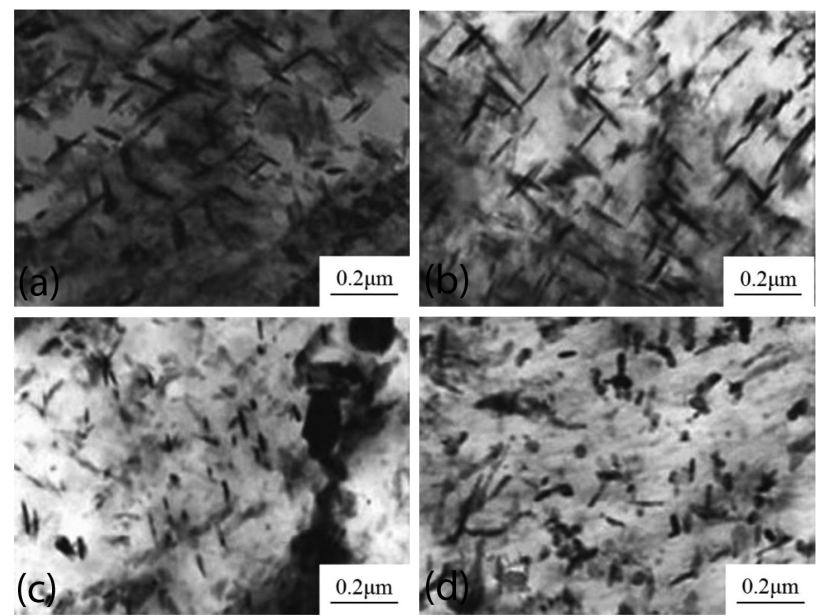

Figure 9: TEM micrographs of 34CrNiMo6 specimens quenched in oil $\left(870{ }^{\circ} \mathrm{C} / 30 \mathrm{~min}\right)$ and tempered at different tempering temperatures: a) as quenched in oil $\left(870{ }^{\circ} \mathrm{C} / 30 \mathrm{~min}\right)$, b) quenched and tempered at $630{ }^{\circ} \mathrm{C}$ for $3 \mathrm{~h}$, c) quenched and tempered at $660{ }^{\circ} \mathrm{C}$ for $3 \mathrm{~h}, \mathrm{~d}$ ) quenched and tempered at $690{ }^{\circ} \mathrm{C}$ for $3 \mathrm{~h}$ 

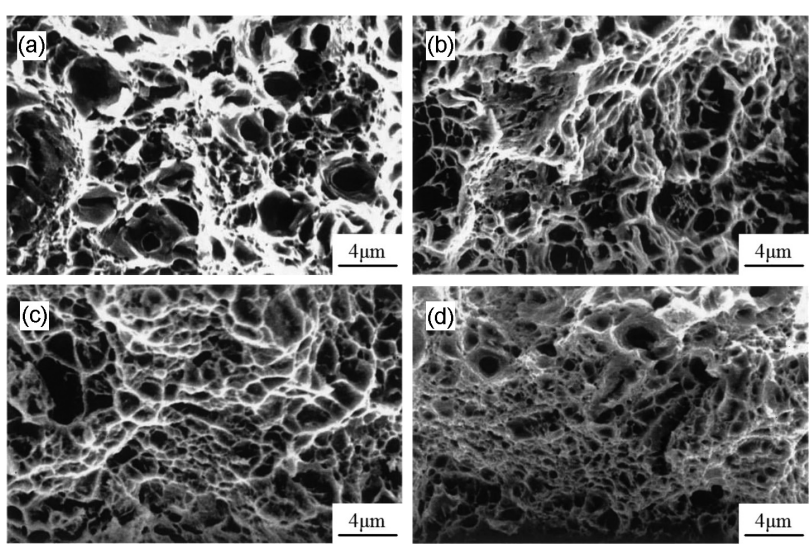

Figure 10: Fracture morphologies of specimens quenched in oil $\left(870{ }^{\circ} \mathrm{C} / 30 \mathrm{~min}\right)$ and tempered at different tempering temperatures: a) as quenched in oil $\left(870^{\circ} \mathrm{C} / 30 \mathrm{~min}\right)$, b) quenched and tempered at $570{ }^{\circ} \mathrm{C}$ for $\left.3 \mathrm{~h}, \mathrm{c}\right)$ quenched and tempered at $630{ }^{\circ} \mathrm{C}$ for $3 \mathrm{~h}$ d) quenched and tempered at $660^{\circ} \mathrm{C}$ for $3 \mathrm{~h}$

complete with the recommended tempering temperature, resulting in a decrease in mechanical properties and improvement of ductility. This conclusion is consistent with the previous one.

Fracture morphologies of the specimens quenched in oil and tempered at different tempering temperatures are shown in Figure 10.

As shown in Figure 10, fracture characteristics are always dominated by the ductile mechanism for all the tempered specimens. The features observed from the micrographs are typical of most of the fracture surfaces at all the tempering temperatures. Moreover, the voids in these micrographs exhibit a wide variation in the size and shape, indicating that localized shear stresses may occur in addition to tensile stresses during the deformation process. It should be pointed out that although some voids existed in the fracture initiation area, there is no certain evidence proving that these voids were caused by carbides.

\section{CONCLUSIONS}

The paper investigates the microstructure evolution during the heat treatment of the $34 \mathrm{CrNiMo6}$ steel by varying the tempering temperatures. In the experiments, five different tempering temperatures are adopted, with the same holding time. The following conclusions can be drawn based on the experimental results:

(1) Both the tensile strength and yield strength decrease with the increasing tempering temperature. In contrast, the elongation after breakage increases with the increasing tempering temperature up to $660{ }^{\circ} \mathrm{C}$, while remaining almost stable from $660{ }^{\circ} \mathrm{C}$ to $690{ }^{\circ} \mathrm{C}$. The Rockwell hardness $\mathrm{C}$ decreases with the increasing tempering temperature up to $660^{\circ} \mathrm{C}$, while remaining almost stable from $660{ }^{\circ} \mathrm{C}$ to $690{ }^{\circ} \mathrm{C}$.

(2) The impact-absorbing energy increases with the increasing tempering temperature and then decreases between $660{ }^{\circ} \mathrm{C}$ and $690{ }^{\circ} \mathrm{C}$ when the testing tempera- ture is $20{ }^{\circ} \mathrm{C}$. The impact-absorbing energy increases monotonously with the increasing tempering temperature when the testing temperature is $-40{ }^{\circ} \mathrm{C}$.

(3) Based on the mechanical properties determined during the testing under steady-state conditions and impact conditions, and the related certification standard, it is highly recommended that the tempering temperature should be $630-660^{\circ} \mathrm{C}$.

(4) The differences in the mechanical properties determined at different tempering temperatures may be caused by the nucleation rate and growth of precipitates under different conditions. The spherification degree of cementite is more complete with the recommended tempering temperature, resulting in a decrease in mechanical properties and improvement in ductility.

(5) The fracture characteristic is always dominated by the ductile mechanism for all the tempered specimens. The voids in the micrographs exhibit a wide variation in the size and shape, indicating that localized shear stresses may occur during the deformation process. Although some voids existed in the fracture initiation area, there is no certain evidence proving that these voids were caused by carbides.

\section{REFERENCES}

${ }^{1}$ M. R. Islam, S. Mekhilef, R. Saidur, Progress and recent trends of wind energy technology, Renewable Sustainable Energy Rev., 21 (2013), 456-468, doi:10.1016/j.rser.2013.01.007

${ }^{2}$ F. Díaz-González, A. Sumper, O. Gomis-Bellmunt, R. Villafáfila-Robles, A review of energy storage technologies for wind power applications, Renewable Sustainable Energy Rev., 16 (2012) 4, 2154-2171, doi:10.1016/j.rser.2012.01.029

${ }^{3}$ O. Ellabban, H. Abu-Rub, F. Blaabjerg, Renewable energy resources: Current status, future prospects and their enabling technology, Renewable Sustainable Energy Rev., 39 (2014), 748-764, doi:10.1016/j.rser.2014.07.113

${ }^{4}$ Q. Zhou, X. T. Xia, Y. P. Zhang, Optimal design of mainshaft bearing for wind turbine, Adv. Mater. Res., 171-172 (2011), 252-255, doi:10.4028/www.scientific.net/AMR.171-172.252

${ }^{5} \mathrm{M}$. Calcagnotto, D. Ponge, D. Raabe, Effect of grain refinement to 1 $\mu \mathrm{m}$ on strength and toughness of dual-phase steels, Mater. Sci. Eng.: A, 527 (2010) 29, 7832-7840, doi:10.1016/j.msea.2010.08.062

${ }^{6}$ H. Chunping, L. Xin, L. Fencheng, C. Jun, L. Fenggang, H. Weidong, Effects of cooling condition on microstructure and mechanical properties in laser rapid forming of 34CrNiMo6 thin-wall component, Int. J. Adv. Manuf. Technol., 82 (2016) 5, 1269-1279, doi:10.1007/s00170-015-7453-z

${ }^{7}$ W. Musial, J. Allread, Test methodology and control of full-scale fatigue tests on wind turbine blades, Wind Energy, (1993), 199

${ }^{8}$ A. K. Belyaev, A. M. Polyanskiy, V. A. Polyanskiy, C. Sommitsch, Y. A. Yakovlev, Multichannel diffusion vs TDS model on example of energy spectra of bound hydrogen in 34CrNiMo6 steel after a typical heat treatment, Int. J. Hydrogen Energy, 41 (2016) 20, 8627-8634, doi:10.1016/j.ijhydene.2016.03.198

${ }^{9}$ N. Popescu, M. Cojocaru, V. Mihailov, Experimental studies on bulk tempering of $34 \mathrm{CrNiMo6}$ steel, Surf. Eng. Appl. Electrochem., 48 (2012) 1, 28-34, doi:10.3103/S1068375512010139

${ }^{10}$ J. Cochet, S. Thuillier, T. Loulou, N. Decultot, P. Carré, P. Y. Manach, Heat treatment of 34CrNiMo6 steel used for mooring shackles, Int. J. Adv. Manuf. Technol., 91 (2017) 5, 2329-2346, doi:10.1007/s00170-016-9951-z 
${ }^{11}$ Z. Zhang, Z. Yin, T. Han, A. C. C. Tan, Fracture analysis of wind turbine main shaft, Eng. Failure Anal., 34 (2013), 129-139, doi:10.1016/j.engfailanal.2013.07.014

${ }^{12}$ R. Wang, T. Han, W. Wang, Y. Xue, D. Fu, Fracture analysis and improvement of the main shaft of wind turbine based on finite element method, Adv. Mech. Eng., 10 (2018) 4, doi:10.1177/ 1687814018769003

${ }^{13}$ H. D. Sun, K. Y. Zhao, J. Q. Rui, W. Jiang, X. C. Han, Q. L. Yong, J. $\mathrm{Su}$, Effect of tempering process on structure and properties of super martensitic stainless steel, Adv. Mater. Res., 581-582 (2012), 1023-1026, doi:10.4028/www.scientific.net/AMR.581-582.1023

${ }^{14}$ D. N. Zou, Y. Han, W. Zhang, X. D. Fang, Influence of tempering process on mechanical properties of $00 \mathrm{Cr} 13 \mathrm{Ni} 4 \mathrm{Mo}$ supermartensitic stainless steel, J. Iron Steel Res. Int., 17 (2010) 8, 50-54, doi:10.1016/S1006-706X(10)60128-8

${ }^{15}$ A. Chatterjee, D. Chakrabarti, A. Moitra, R. Mitra, A. K. Bhaduri, Effect of normalization temperatures on ductile-brittle transition temperature of a modified $9 \mathrm{Cr}-1 \mathrm{Mo}$ steel, Mater. Sci. Eng. A, 618 (2014), 219-231, doi:10.1016/j.msea.2014.09.021
${ }^{16}$ H. Muhammad Arslan, F. Ameeq, Microstructural, mechanical and tribological investigation of 30CrMnSiNi2A ultra-high strength steel under various tempering temperatures, Mater. Res. Express, 5 (2018) 1, 016505, doi:10.1088/2053-1591/aa9fd3

${ }^{17}$ G. Miyamoto, N. Takayama, T. Furuhara, Accurate measurement of the orientation relationship of lath martensite and bainite by electron backscatter diffraction analysis, Scr. Mater., 60 (2009) 12, 1113-1116, doi:10.1016/j.scriptamat.2009.02.053

${ }^{18}$ A. Shibata, F. Ichikawa, H. Adachi, T. Yamasaki, N. Tsuji, Cooperative strain accommodation over grains in martensitic transformation from Fe-Ni nanocrystalline austenite, Philos. Mag. Lett., 97 (2017) 4, 132-139, doi:10.1080/09500839.2017.1292057

${ }^{19}$ N. V. Luzginova, L. Zhao, J. Sietsma, The cementite spheroidization process in high-carbon steels with different chromium contents, Metall. Mater. Trans. A, 39 (2008) 3, 513-521, doi:10.1007/s11661007-9403-3 